\title{
Música e culto religioso Estudo do acompanhamento musical das procissões atenienses conforme o testemunho dos textos antigos e da cerâmica ática tardo-arcaica e clássica
}

\author{
FÁBIO VERGARA CERQUEIRA \\ Universidade Federal de Pelotas
}

RESUMO: A música era um elemento constitutivo do ritual grego, desempenhando um importante papel, tanto cerimonial quanto místico. Estudamos o acompanhamento musical das procissões, enfocando o caso ateniense, testemunhado pelo registro da iconografia da cerâmica ática, referente ao mundo de Atenas dos séculos VI e V a.C. A documentação iconográfica é compreendida em um contexto mais amplo da religiosidade grega, estabelecendo-se comparações, com base nos textos antigos, com outras regiões e outros períodos da Antigüidade Clássica.

PALAVRAS-CHAVE: Grécia Clássica; música; religião; iconografia.

A música era um componente indispensável do culto grego, estando presente em quase todas as manifestações religiosas: libações e sacrifícios não se efetivavam sem acompanhamento musical (Pap. de Oxyrrhinchos 675, col. I, sobre libações, e col. II, sobre sacrifícios animais). De outro lado, o desenvolvimento da música foi sempre fortemente influenciado pela religião, uma vez que quase todas as formas de performance musical - hinos, ditirambos, coros, agônes musicais, teatro - ligavam-se de algum modo à vida religiosa. É sabido que, com o passar do tempo, a arte musical grega teve um grande desenvolvimento técnico e teórico, o que a levou para além das fronteiras da religião. Todavia, o grande ambiente de performance dessa música que ao mesmo tempo se especializava, se profissionalizava e se profanizava - continuava sendo os festivais religiosos (Haldane, 1966, p. 98; Nordquist, 1992, p. 143).

Para a percepção grega da prática religiosa, o ingrediente da música instrumental era tido como um elemento constitutivo natural, causando estranhamento ao povo grego os costumes de outros povos, diferentes sob esse aspecto. É assim que Heródoto (I.132), na sua vocação para antropólogo, chama atenção para o fato de que os persas não usavam o acompanhamento de instrumentos musicais em seus rituais de sacrifício. No fundo desse costume grego, estava a crença de que a música era um agente propiciatório da comunicação entre o humano e o divino: ela seria necessária para que o deus aceitasse o sacrifício. Uma história sobre o famoso auletés tebano Ismênias, narrada por Plutarco (Propostas de Mesa II.1.632c-d), é bastante esclarecedora 
a esse respeito: o músico tebano, conhecido por seu virtuosismo e riqueza, estava tocando durante um sacrifício, mas o deus parecia não ouvir a sua música, de modo que o serviço religioso se tornava inoperante, não obstante empregarem um músico bem sucedido artística e financeiramente; chamou-se então um músico humilde, e o deus, por fim, aceitou o sacrifício. A música era então utilizada para que o deus ouvisse os apelos humanos, como ocorreu no caso de um fugitivo, que sensibilizou Zeus através de uma melodia executada com um aulós lídio (Píndaro, Olimpicas V.45). A mesma finalidade da música fica evidente em outra situação: durante os sacrifícios realizados nos campos de batalha, nos quais a música era um componente necessário para que o deus atendesse aos pedidos de seus seguidores e lutasse ao lado deles ${ }^{1}$.

Havia a possibilidade de um sacrifício ser efetivado sem música. A ausência da música era uma regra nos rituais dedicados a divindades ctônicas, como é o caso do culto às Cárites, em Paros (Apollodoros, Biblioteca III.15-7; Haldane, 1966, p. 106). De resto, a retirada dos instrumentos musicais era entendida como prejudicial, comprometendo os verdadeiros sentimentos dos cultos e festivais (Plutarco, Non posse suav. Vivi sec. Epic. 1102 A). As referências a sacrifícios que pudessem ser efetivados sem instrumentos musicais aparecem na documentação literária como exceções - na verdade, parece-nos muito mais um recurso literário para reforçar uma crítica através da absurdidade que seria cumprir o rito sem o músico. Isso fica bem claro em duas situações em que se teria dispensado o músico durante o sacrifício: numa história contada por Ateneu, o excêntrico e genioso citarista Estratônicos teria ordenado que um auletés silenciasse sua música até que se tivessem feito a libação e as orações aos deuses, pois ele seria um músico tão inepto que estaria atrapalhando o ritual (Ateneu, VIII 349c); num trecho da comédia Paz de Aristófanes, o auletés Chéris é dispensado, por ser considerado inoportuno. Tanto a dispensa de Chéris, freqüentemente vilipendiado por Aristófanes, quanto a do auletés, rechaçado por Estratônicos, traduzem um preconceito social em relação aos músicos profissionais, sobretudo em relação aos auletaí de origem humilde que constituíam um proletariado musical atuante nos rituais e funerais (Aristófanes, Paz 950-1; Aves 858; Acarnianas 16 e 866; Nordquist, 1992, p. 163-5; Bélis, 1999, p. 84-6). O desprezo social partia inclusive dos músicos melhor posicionados, como o referido Ismênias, que dizia lastimar o fato de se usar o termo auletés para os músicos que trabalhavam nos funerais (Apuleu, Florides IV 3; Díon Chrisóstomos, Discursos XLIX.12.) $)^{2}$. O preconceito em relação a esses músicos de baixo escalão social se faz sentir inclusive entre os pintores de vasos, nomeadamente aqueles da técnica de figuras vermelhas, que retrataram com mais freqüência cenas de sacrifícios. G. Nordquist (1992, p. 166) chama nossa atenção para o fato de que as cenas de sacrifício costumam ser representadas sem a presença do músico - sabemos, no entanto, que isso não significava de forma alguma que os atenienses do séc. V praticassem seus cultos oficiais sem os músicos. Os pintores retiram os auletaí proletários dos sacrifícios por os julgarem indignos de serem retratados, compartilhando do juízo de Aristófanes a esse respeito.

Desse modo, como a ausência do músico no culto era tratada como uma exceção ou como uma narrativa anedótica, fica confirmada a regra do emprego do músico nos rituais. Em vista disso, causa-nos espécie que tão poucos autores tenham elegido o assunto como objeto de abordagem sistemática. O primeiro estudo dedicado exclusivamente a essa temática é de autoria de J. A. Haldane e foi publicado em 1966. Em seu artigo "Musical instruments in Greek worship", ele desenvolveu uma análise eminentemente literária, usando a iconografia apenas eventualmente, com o fito de comprovar as evidências fornecidas pelo registro escrito. Transitou no 
universo das fontes com excessiva liberdade cronológica, praticando disparidades temporais: por exemplo, utilizou o sarcófago minoano de Haghia Triada, lado a lado com vasos beócios e com os frisos do Partenon, como evidência iconográfica comprobatória dos testemunhos literários clássicos e helenísticos. Concentrou seus esforços em provar que o aulós era o instrumento central no culto (justificando esse fenômeno pela força de seus sons incisivos), apesar do mérito de reconhecer o uso de outros sopros e cordas em rituais mais suntuosos, elencando suficientes registros documentais que derrubaram a visão simplista da exclusividade do aulós nos atos religiosos. Destacou a multiplicidade de instrumentos nos cultos dionisíacos, antecipando a análise que seria feita exatamente vinte anos mais tarde por Annie Bélis (Bélis, 1986, p. 9-29). Do ponto de vista organológico, cometeu o erro imperdoável de misturar indistintamente kithára, chélys (lýra) e phórminx, distinções classificatórias que já estavam devidamente estabelecidas pela obra de Max Wegner, entre outros. Por exemplo, quando está referindo-se aos hinos homéricos, menciona a kithára, quando na verdade o instrumento citado nesses textos seria ou a phórminx homérica ou a chélys (lýra), como ocorre no Hino homérico a Ártemis (v. 19).

Foram necessários vinte e seis anos para que viesse a público um novo estudo geral dedicado à música praticada no culto religioso. Em 1992, foi publicado o artigo da arqueóloga norueguesa Gullög Nordquist, "Instrumental music in representation of Greek cult". A autora decide estabelecer um contraponto ao estudo literário de Haldane, procurando, com base no registro iconográfico dos vasos áticos, responder as seguintes questões: Em que momento do culto os instrumentos eram usados? Quais os instrumentos utilizados nessas situações? Quem os tocava? Qual era a relação do músico com o culto e com os outros participantes? Nesse estudo, Nordquist analisou o material iconográfico dividindo-o em duas situações do ritual: as procissões e os sacrifícios, evitando entrar na problemática diferenciada dos cultos orgiásticos, nos quais a questão da música se coloca de forma bastante específica. Para a compreensão das representações da música no culto, destaca, em sua análise, a abordagem diferenciada que os pintores áticos conferiram às procissões e aos sacrifícios, como já o havia enfatizado K. Lehnstaedt. A temática das procissões aparece sobretudo na obra dos pintores de figuras negras, predominando o interesse pelo culto coletivo da pólis, sobretudo por aqueles dedicados à deusa Atena. Os sacrifícios foram assunto sobretudo dos pintores de figuras vermelhas, que abandonaram a preferência pelos grandes grupos participando nos rituais, optando por cenas com poucos personagens, nas quais os atos religiosos eram retratados numa linguagem sinóptica, condensando na mesma cena várias etapas do ritual; o interesse desses pintores voltou-se bastante para os cultos particulares, com uma predileção particular por cenas de culto a Apolo (Lehnstaedt, 1970; Nordquist, 1992, p. 165-6). Do ponto de vista musical, G. Nordquist ousou utilizar a iconografia como ferramenta para questionar um dos preceitos básicos da historiografia da música grega antiga, o primado da monodia: apresentou provas bastante consistentes acerca da prática da sinaulía nas procissões. Nós nos irmanamos com essa autora no intuito de comprovar que os gregos eventualmente praticavam a música orquestrada em seu cotidiano, tendo o conhecimento prático da harmonização, mesmo que feita de modo a respeitar a simplicidade harmônica. Gullög Nordquist publicou recentemente outros dois estudos sobre a música no ritual, abordando sistematicamente temas que até agora só haviam sido tratados de forma marginal. Num deles dedicou-se ao uso da salpínx, no outro, aos músicos (Nordquist, 1994, p. 241-56; "Some notes on musicians in Greek cult", p. 81-93). 
Alguns autores se dedicaram a estudar a música empregada em alguns cultos religiosos específicos. Apostolos Athanassakis escreveu em 1970 um estudo sobre a música no ritual eleusino, deduzindo que os instrumentos utilizados eram principalmente o aulós e o týmpanon, baseado numa análise etimológica dos nomes dos personagens referidos nos mitos concernentes à chegada de Deméter a Elêusis. Do mesmo modo que Haldane, Athanassakis sustentou-se precipuamente em fontes literárias, recorrendo timidamente, em uma única nota de rodapé, à lembrança de um documento iconográfico (Athanassakis, 1970, p. 86-104, nota 81). Annie Bélis dedicou um artigo à música do cortejo dionisíaco, no qual aponta a existência de uma sonora "orquestra dionisíaca", composta sobretudo por sopros, percussões e vozes, com o intuito de produzir contrastes musicais violentos, que resultam numa música dominada pelos extremos, governada pelas percussões não melodiosas, pelo agudo da voz feminina e pela rouquidão grave do aulós frígio. Lembra, porém, que a iconografia testemunha o uso do bárbitos no cortejo dionisíaco, que seria conveniente devido ao som grave de suas longas cordas. Segundo A. Bélis, "o efeito imediato dessa oposição é de provocar entre os participantes uma tensão à qual se acrescenta o frenesi causado pela aceleração dos ritmos batidos pelas percussões: o transe aprofunda-se, a dança torna-se cada vez mais rápida" (Bélis, 1986, p. 9-29). A autora mantém, no entanto, a concepção de que o aulós é o instrumento dionisíaco por excelência, devido a seu efeito orgiástico e passional, apontado por Aristóteles (Política VIII.1342).

Em nosso estudo iconográfico do acompanhamento musical das procissões religiosas, interessam as práticas musicais adotadas durante as procissões e o contexto de utilização dos instrumentos. Nesse sentido, aproximamo-nos bastante da perspectiva seguida nos textos de Gullög Nordquist. Observamos, na iconografia da cerâmica ática registrando procissões religiosas, os seguintes instrumentos: aulós, lýra, kithára, bárbitos e salpínx.

Com base nos dados sistematizados em nosso catálogo iconográfico, chegamos então aos seguintes resultados:

\section{Procissões em geral}

Entre as procissões, excluídos aqui os exemplos de pompaí, encontramos três exemplos com lýra (cat. $1 ; 2 ; 3)^{3}, 12$ exemplos com o aulós, em situações bastante variadas (cat. 4 , fr. 2574 e fr. $2575 ; 5 ; 6 ; 7 ; 8 ; 9 ; 10 ; 11 ; 12 ; 13 ; 14)$, dois fragmentos com a combinação de bárbitos e kithára (cat. $15 ; 16)^{4}$.

No que se refere ao uso pouco comum da lýra nas procissões, o documento mais antigo é uma ânfora parisiense ático-corintizante (cat. 1), datada de meados do séc. VI, sobre a qual vemos um cortejo de quatro homens tocando lýra, executando passos elaborados de dança ou marcha. Giron-Bistagne identifica um coro ditirâmbico, no seu modo transicional, abandonando a forma coreográfica, o dito hypórchema, e aderindo à forma coral, desenvolvida por Lasos de Hermíone e consagrada em Atenas na época das reformas de Clístenes, forma que predominou a partir dos finais do séc. VI, quando o ditirambo se afastou cada vez mais de sua natureza religiosa e se tornou um gênero competitivo da arte coral, de aspecto sério: nessa ânfora parisiense, nas palavras da autora, "a dança dos cantores-músicos se reduz a uma marcha ritmada" (Ghiron-Bistagne, 1976, p. 296, fig. 152-3). Há, porém, um problema de cronologia na interpretação proposta por Ghiron-Bistagne: a 
datação do vaso, com a zona inferior decorada com aves, quadrúpedes e sereias, típicas da cerâmica coríntia, caracteriza o estilo ático-corintizante, próprio das primeiras décadas do séc. VI. Encontramos, assim, um anacronismo entre esta ânfora e o contexto analítico das últimas décadas do séc. VI, no qual Ghiron-Bistagne pretende inseri-la. Todavia, é possível outra interpretação, à luz do Hino homérico a Apolo (v. 201 e 515). Esta ânfora áticocorintizante lembra, no entanto, os passos executados pelo próprio deus, ao som da phórminx - a homérica, no caso -, quando conduziu os marinheiros cretenses ao templo délfico. Desse modo, podem constituir passos de uma marcha processional dedicada a Apolo, ao som da lýra, tal qual estipulava a referência mitológica do hino. É possível pensarmos em Apolo sendo festejado na sua qualidade de Apolo komaîos, deus da festa e do lirismo. Esse deve ser o sentido do citarista dançando, com a perna elevada num movimento semelhante aos músicos da ânfora ático-corintizante de Paris (cat. 1), sobre uma kýlix da técnica dita "de Siana", atribuída ao Pintor de Taras e datável da década de 60 do séc. VI a.C.: vemos um jovem dançando, com sua kithára, próximo de uma árvore, que propomos aqui identificar com o deus Apolo, inspirado na ação descrita no referido trecho do Hino homéricos.

Sobre um skýphos do Museu Nacional (cat. 3), datado de aproximadamente 585-80 a.C., encontramos uma procissão com eminente caráter dionisíaco: os fiéis avançam com dignidade cultual, levando consigo oferendas alusivas à festa patroneada por Dioniso, o sympósion - identificamos então, entre as oferendas, kérai, skýphoi, karchésia, kántharoi. Como sabemos, no entanto, o banquete não é lugar somente de beberagem, pois a música desempenha função de igual relevância, de modo que a lýra - nesse período ainda bastante ativa no banquete (cat. 17; 18;19) ${ }^{6}$, tendo em vista a introdução do bárbitos em Atenas ter ocorrido apenas seis décadas mais tarde - integra coerentemente o conjunto de objetos ofertados a Dioniso, estando nas mãos do fiel que lidera o cortejo.

O único exemplo de procissão sacrificial com uso da lýra para acompanhamento instrumental se encontra sobre a oinochóe de figuras negras Orvieto 1001 (cat. 20), do Pintor de Amásis, datada de aproximadamente 560-50 a.C. A partir da segunda metade do séc. VI, constatamos a predominância absoluta do aulós no contexto do acompanhamento instrumental das procissões. Efetivamente, conforme o testemunho literário, o aulós atuava no acompanhamento do refrão do peã ou do canto do hino processional, chamado prosódion, apesar de também poder ser tocado sozinho, como solo instrumental (Haldane, 1966, p. 99; Nordquist, 1992, p. 144. Cf. Aristófanes, Aves 857-8; Pausânias, VIII.38.8.).

As prosódia eram parte integrante das procissões sacrificiais e dos coros processionais. Proclus, na sua obra Chrestomatheia, incluía o acompanhamento do aulós na sua definição do prosódion. Não podemos esquecer que os famosos auletaí Pronomos e Clonas notabilizaram-se como compositores de prosódia (Haldane, 1966, p. 99; Nordquist, 1992, p. 144. Cf. Plutarco, De Musica 1132c; Pausânias, IX.12.6.). O aulós era uma constante mesmo em procissões religiosas em que a canção entoada não era um hino religioso ou peã: durante o ritual do hierós gámos, bonecas eram levadas ao Citerão, vestidas de noivas, numa procissão acompanhada pela música do aulós e pelo canto do himeneu (Ovídio, Amores III.13.11-12.).

A presença do aulós no acompanhamento das procissões sé dá substancialmente sob duas formas, que correspondem a duas expressões cultuais distintas: o coro e a procissão 
sacrificial. No acompanhamento de coros - que no caso constituem o culto em si, pelo qual, em homenagem a um deus, se canta um hino ou peã e se executa uma dança adequada -, o aulós tem uma finalidade propriamente musical, uma vez que a essência desse rito é musical. A atitude desses coros, mais séria ou mais jocosa ou orgiástica, depende da natureza do ritual. Nas procissões sacrificiais, o aulós é o instrumento que dá o ritmo e o acompanhamento melódico do cortejo, cuja finalidade é conduzir a vítima até o santuário onde essa será imolada e ofertada ao deus. Nesse caso, sua função está ligada a uma intermediação, intermediação entre oficiantes de culto e deus homenageado, entre oficiantes e público, entre culto e vítima.

Encontramos na iconografia vários exemplos em que o auletés integra um coro que homenageia alguma divindade, tanto em procissões como em cultos diante de altar, em cenas registradas pelos pintores de figuras negras e vermelhas. Em nosso catálogo, arrolamos exemplos que ilustram essa situação: cinco em procissões (cat. $5 ; 6 ; 7 ; 10 ; 11$ ) e dois em culto com dança em torno de altar (cat. 21;22), além dos casos ligados diretamente ao culto dionisíaco das Antestérias, com aulós numa procissão de bacantes de ânimo controlado e calmo (cat. 23), bem como rituais dançantes diante do altar (cat. 24) ou em cortejo agitado (cat. 25).

Por via de regra, os coros dançantes integram rituais praticados por mulheres. No fragmento do pé de um loutrophóros de Atenas (cat. 6), vemos um coral de moças trajando péplos realizando dança ritual ritmada pela música de uma auletrís, que se distingue das demais pela sua indumentária, um khitón pregueado, com mangas pelos cotovelos. Sobre uma cratera do Pintor de Villa Giulia (cat. 7), vemos um coral de moças, de mãos dadas, seguindo a música de uma auletrís, enquanto executa uma dança de roda de caráter bastante contido. As moças deviam estar entoando um parthénion, enquanto dançavam em roda junto a um templo, como sugere a coluna representada por detrás delas. A dança acompanhada pelo aulós também tem um papel importante em rituais de ofertório junto a um altar, sobretudo em libações praticadas por mulheres. Num complicado quebra-cabeças de fragmentos incompletos de uma cratera campaniforme proveniente da Acrópole de Atenas (cat. 21), identificamos um coral de moças dançando no ritmo da música de uma auletrís, enquanto se procede a uma libação sobre o altar que deverá receber o sacrifício de um cervídeo - a música do aulós tem a dupla função ritualística de embalar a dança coral e propiciar a aceitação da libação. Sobre uma pyxís de figuras vermelhas de Atenas (cat. 22), o pintor retratou os preparativos de uma libação, quando um grupo de moças dança e uma mulher, sentada sobre um klismós, toca aulós diretamente diante do altar - indicando a função da música ao mesmo tempo como intermediária da comunicação com o deus homenageado e como uma oferenda em si.

As fontes literárias também apontam o aulós como o instrumento musical que acompanhava o parthénion (Ateneu, XIV.634sq.), não obstante a possibilidade do hino cantado durante a dança coral de moças virgens receber o acompanhamento do aulós e da lýra (Alcman frs. 66 e 78 Bergk). Presumimos que o aulós fosse o instrumento predominante na forma processional dos parthénia, enquanto nas danças de roda seria possível empregar alternativamente qualquer um dos dois (Haldane, 1966, p. 104). Uma evidência bastante interessante a esse respeito se encontra numa hydría ática de Nápoles, na qual vemos uma 
instrumentista na função de regente de um coro de moças: ela está trocando o aulós pela lýra, o que indica que diferentes momentos da performance demandavam acompanhamentos instrumentais distintos (Furtwängler e Reichhold, 1932, p. 171).

Os coros masculinos parecem traduzir uma atmosfera mais contida, como devia ser recomendado em cultos cívicos, mesmo quando o deus homenageado era Dioniso. Esse é provavelmente o caso de três vasos de nosso catálogo. Numa kýlix de figuras negras do Pintor do B.M.N. (cat. 10), um auletés acompanha uma procissão circunspecta, marcada pela elegância dos trajes dos partícipes e pela atitude sóbria desses, o que confere uma certa pompa oficial à celebração. Alguns dos fiéis levam consigo um kéras, apontando-nos a provável identidade do deus homenageado - Dioniso. Uma cena bastante semelhante está representada sobre uma ânfora contemporânea do Pintor do Balanço (cat. 5), na qual, no entanto, não conseguimos identificar a divindade cultuada. Sobre a superfície interna de uma kýlix parisiense do Pintor de Triptolemo (cat. 11), temos uma área decorada dividida em duas áreas: medalhão e entorno. No entorno do medalhão, o pintor representou uma procissão, composta por treze pares masculinos, ligados provavelmente por laços de philía, como indica o fato de se resguardarem sobre a mesma khlaîna ${ }^{7}$. O grupo é liderado pelo auletés e por um corifeu, que, com a mão direita espalmada erguida, guia o conjunto. Trata-se de um coro misto, formado por homens e jovens livres, pertencentes à categoria dos cidadãos - o coro misto convinha à socialização artística de grupos de amigos e amantes, adultos e jovens, que costumavam encontrar-se e divertir-se nos banquetes, festas patroneadas por Dioniso. E esse era precisamente o deus homenageado por este coro, como indica a cena do medalhão, com um garoto oferecendo uma libação a Dioniso. Conforme A. Bélis, o vaso representaria um coro de ditirambo, integrando então algum concurso musical ligado a Dioniso (Bélis, 1999, p. 146, fig. 1).

Nestes três vasos, o auletés se destaca, pela sua indumentária, como uma figura à parte no conjunto dos participantes do culto. Nos três casos, além do khitón, eles vestem uma peça especial, típica dos auletaí profissionais, o ependýtes: uma blusa sem mangas, finamente enfeitada com bordados com motivos geométricos, colocada sobre o khitón, cobrindo-lhe até pouco abaixo da cintura, mas mantendo livre a movimentação dos braços. Na ânfora de Nápoles (cat. 5) e na kýlix de Paris (cat. 11), o músico usa também uma phorbeiá, útil para longas performances musicais, tais como procissões cujo percurso pode ser bastante demorado, garantindo-lhe que consiga administrar bem a força da emissão necessária de ar. A iconografia mostra-nos que, muito embora os membros dos coros no período tardo-arcaico e clássico proviessem da categoria dos cidadãos, para a função de auletés costumava-se contratar músicos profissionais. Entre os rituais femininos, era mais comum que as auletrídes fossem musicistas amadoras, pertencentes ao mesmo grupo das demais coralistas, apesar de que a roupa da auletrís do loutrophóros de Atenas (cat. 6) aponta para a possibilidade de uma musicista profissional.

O aulós aparece em vários exemplos de procissões sacrificiais, a maioria delas representadas pelos pintores de figuras negras. Os pintores áticos se especializaram em representar dois momentos distintos da procissão com a vítima sacrificial: o percurso festivo pelas ruas e a chegada do cortejo ao santuário (estágio que antecede o sacrifício). Exclusivamente os pintores de figuras negras representaram o percurso da procissão sacrificial, com a rara exceção de um fragmento de Menidi contemporâneo dos frisos do Partenon (cat. 26) (Lehnstaedt, 1970; Nordquist, 1992, p. 165-6). Já as cenas de chegada ao santuário, são representadas por pintores das duas técnicas. 
Dois fragmentos de pínax provenientes da Acrópole de Atenas (cat. 4) fornecem exemplo da atuação do auletés ao longo do percurso. Sobre o fragmento 2574 , quatro mulheres avançam em cortejo, trazendo, entre outras oferendas, duas corsas; o passo dessas fiéis é ritmado pela música do aulós executado por um jovem com khitón, himátion e phorbeiá. No fragmento 2575, em que o jovem é substituído por um adulto com barba na função de auletés, as oferendas representadas não incluem um animal: destacam-se duas kanephóroi e uma mulher com um tridente. No primeiro fragmento, os ramos de louro e as corsas nos fazem pensar em uma procissão dedicada a Apolo; no segundo fragmento, o tridente nos sugere que o deus cultuado fosse Posseidon.

Inserimos em nosso catálogo dois interessantes exemplos de procissão sacrificial dedicada a Dioniso. No skýphos do Pintor de Teseu conservado em Stuttgart (cat. 13), encontramos um tipo de procissão que costuma ser identificada por Beazley como dionisíaca ${ }^{8}$.Diferentemente das procissões mais formais e sofisticadas, vemos aqui uma manifestação ritual mais rústica, em que os participantes, inclusive o auletés, estão nus. A nudez de todos indica uma simplicidade e despreocupação com a aparência social do evento, implicando um culto mais particular - a nudez do músico indica, inclusive, que não deve tratar-se de um músico profissional contratado, mas de um amador, um cidadão livre como os demais. A ambiência retratada pelo Pintor de Teseu difere radicalmente da procissão apresentada pelo Affekter (cat. 12), que ilustra, provavelmente, uma pompé realizada durante as Dionisíacas. Num cortejo que percorre as duas faces do vaso, a cena está apresentada até a chegada ao santuário, quando o grupo é recepcionado por uma sacerdotisa posicionada atrás do altar. Entre as oferendas (ramalhetes, guirlandas, bandeja com frutos e alimentos, coroas e lékythoi), destaca-se um carneiro, seguido pelo auletés.

O referido vaso de Affekter (cat. 12), bem como a ânfora do Pintor de Kleophon (cat. 8) e um lékythos da coleção da Acrópole (cat. 27) mostram a chegada da procissão ao santuário. Cada um deles retrata uma procissão distinta, no que se refere à divindade homenageada: num caso, Dioniso (cat. 12), noutro, Atena (cat. 27). Na ânfora ateniense (cat. 8), temos uma situação bem distinta: além de não podermos deduzir a identidade do deus cultuado, o vaso apresenta a peculiaridade de apresentar um culto privado e mais informal, com a participação de um menino em idade escolar como auletés. Trata-se de mais um exemplo do maior interesse dos pintores de figuras vermelhas da segunda metade do séc. $V$ pelo universo da vida privada, mesmo em sua dimensão religiosa, enquanto os pintores de figuras negras, da segunda metade do séc. VI e primeiros anos do séc. $\mathrm{V}$, preferiam enfatizar a dimensão pública, comunitária, abordando as procissões sacrificiais como expressões da vida coletiva.

\section{Grandes procissões públicas (pompaí panatenaicas e eleusinas)}

Dentro desse espírito de valorização das manifestações da vida coletiva, como forma de enaltecimento do sentimento comunitário, que, desde as reformas de Drácon e Sólon, tendeu a aumentar - mesmo na tirania de Pisístrato, com o apelo populista de sua política cultural -, os pintores de vaso áticos nutriram um particular interesse pelas representações da mais importante de todas as procissões atenienses, a pompé realizada a cada quatro anos por ocasião das Grandes Panatenéias. É assim que encontramos, então, uma série de vasos 
áticos de figuras negras, datados com segurança entre 560 e 500, apresentando a grande procissão panatenaica, que percorria a pólis do Pireu à Acrópole através da via panatenaica (cat. 28; 29; 30; 31; 32). O exemplar anterior a essa data, uma kýlix londrina (cat. 33), é atribuído por vários autores modernos a uma oficina beócia, não obstante poder tratar-se de uma imitação beócia de um original ático, que seria o único exemplo completo da procissão anterior à reformulação das Panatenéias em 566. Desse modo, não constitui um documento seguro para ilustrar a atividade dos músicos nesses cortejos. O único exemplar de figuras vermelhas, datado de pouco depois da metade do séc. V (cat. 26), registra provavelmente a influência do modelo do friso do Partenon, como comprova o fato de ser o único vaso (salvo os dois exemplares da primeira metade do séc. VI - cat. 33 e 28), que apresenta o cortejo avançando da direita para a esquerda, do mesmo modo como no referido friso.

Os pintores áticos são, porém, unânimes num aspecto: a complexidade do acompanhamento musical destas procissões. Nesse sentido, no tocante à musicalização das pompaí, corroboram alguns testemunhos literários para regiões e épocas variadas do espaço cultural grego. Conforme o esplendor da situação, outros instrumentos eram acrescidos. De acordo com uma inscrição, sabemos que a procissão de Zeus Sosípolis em Magnésia contava com a participação de auloí, syringes e kithárai (SIG ${ }^{3} 589,1.46$. Haldane, 1966, p. 99). Na procissão deliana de comemoração do retorno dos Hiperbóreos, exigiam-se os mesmos instrumentos (Plutarco De Musica 1136a). A literatura, bem como a representação da pompé eleusina sobre um loutrophóros (cat. 34), mostram que o modelo de acompanhamento musical da procissão das Grandes Panatenéias não era um fenômeno isolado, mas uma constante nas grandes procissões religiosas públicas.

As pompaí panatenaicas eram acompanhadas por espécies de bandas de música, com a participação de instrumentos de sopro (o aulós) e cordas (a lýra ou a kithára). Essa composição musical desfazia-se no momento em que a procissão chegava ao santuário, quando se iniciavam os preparativos para os sacrifícios - os kitharistaí se afastavam, e um dos auletaí permanecia, assumindo um papel distinto daquele que desempenhara até aí. Temos então duas situações distintas de apresentação da procissão panatenaica, seguindo um esquema geral de representação das cenas de procissão: o momento do cortejo e o momento da chegada ao santuário. Nas duas situações, observamos uma continuidade do modelo apresentado pela iconografia, o que sugere a manutenção das tradições no que se refere às Panatenéias.

O documento mais antigo é a kýlix Londres B 80 (cat. 33), datada de aproximadamente 580, que, como afirmamos anteriormente, deve referir-se às penatenéias que seguiam o modelo anterior às reformas da época da tirania, mesmo se tratando de uma imitação beócia. A cena, apresentada sobre o friso circular interno, representa a chegada do cortejo ao santuário de Atena Promachos. Uma coluna dórica marca o espaço arquitetônico do templo, diante do qual se vê uma hélix que sustenta a imagem de uma serpente, colocada atrás do ícone da deusa. $\mathrm{O}$ altar com lume aceso se encontra diante da imagem cultual. Uma sacerdotisa chega com oferendas e seguida por um touro, conduzindo o kômos de fiéis. O animal, conduzido pelo carnífice, é acalmado, em face de seu triste destino, pela música de um aulós. O músico está paramentado com um khitonískos, diferente dos outros partícipes do cortejo, que vêm a pé ou sobre um carro, nus ou com manto. 
Nesta kýlix de Londres, a função do aulós é de apaziguar o espírito do animal sacrificial. Onde vemos o auletés, a vítima e a sacerdotisa diante do altar, não temos mais a procissão propriamente dita, representada no restante da cena, mas o momento que precede o sacrifício. Não temos aí a orquestra panatenaica, mas simplesmente o auletés que acompanha a besta. A mesma situação se repete em outros dois vasos com procissão panatenaica, espaçados entre si por algumas décadas, evidenciando a continuidade do protocolo ritualístico: uma hydría de Caere de meados do séc. VI (cat. 35) e um lékythos de Atenas da virada do século (cat. 27). A presença do auletés e a dispensa dos outros músicos que atuavam na pompé, quando da chegada do cortejo ao templo diante do qual era feito o sacrifício, constatada no caso das Grandes Panatenéias, devia ocorrer igualmente em outras procissões públicas grandiosas que faziam recurso à banda de instrumentistas de sopro e cordas durante o percurso: por exemplo, a chegada da procissão ao templo de Apolo em Megalópolis ocorria "com aulós e com pompé" (Haldane, 1966, p. 99; Pausânias VIII.38.8). A utilização do aulós, nesse momento de uma procissão dedicada a Apolo, comprova a importância ritualística desse instrumento para validação do culto perante as crenças religiosas, haja vista ser muito comum que os cultos apolínios fossem acompanhados em outras circunstâncias pela kithára, como no caso do coral de meninas da comitiva tessaliana em Delfos, que traziam oferendas enquanto dançavam e cantavam um hino, acompanhadas por kithárai (Heliodoros Aeth. III.1 sq. Hino homérico a Apolo 515), ou do peã prosodial dedicado a Apolo no tesouro dos atenienses em Delfos, composto por Limenios, prevendo o acompanhamento da kithára executada pelo próprio poeta-compositor ${ }^{10}$ (Haldane, 1966, p. 100).

A formação orquestral clássica da procissão panatenaica, consagrada aos olhos do grande público moderno pelos frisos do Partenon expostos no Museu da Acrópole, produz, como sugere a iconografia dos vasos, uma sonora e solene orquestração com auloí e kithárai. O modelo encontrado nos frisos do Partenon foi fixado pouco depois dos anos 50 do séc. VI, como testemunha a famosa ânfora de Berlim (cat. 29), com dois auletaí e dois kitharistaí. Uma kýlix de uma coleção privada suíça, datada de 560-50, apresentava já a formação orquestral com sopros e cordas: ali encontramos já os dois auloí; no entanto, em vez da kithára, uma lýra. Como explicarmos que esse seja o único exemplo de procissão panatenaica acompanhada com uma lýra? Ora, até esse momento, a kithára clássica, conhecida como Ásia, ainda não estava suficientemente disseminada na Ática, apesar de que sua popularidade deve ter aumentado na Grécia continental após a introdução do kitharistikós nómos em Delfos, em 558, com a vitória de Aristônicos de Argos. Em torno dos anos 40, a kithára se espraia com muita força na Ática, caindo na predileção dos músicos e no gosto do público que acorria às competições musicais que ocorriam nas Panatenéias tão prestigiadas oficialmente pelo governo de Pisístrato (Simon, 1953, p. 17). Desse momento em diante, da ânfora de Berlim (cat. 29) aos fragmentos de figuras vermelhas de Menidi (cat. 26), a kithára se consagra, ao lado do aulós, na composição da orquestra panatenaica.

Na pintura dos vasos, encontramos uma variedade numérica da composição dessa orquestra: um par de auletaí e um par de kitharistaí (cat. 29; 30); um auletés e kitharistés (cat. 31; 26); e até mesmo um auletés e dois kitharistaí (cat. 32). Não devemos considerar esses números como uma matemática realista, mas sim de forma figurativa: aludem a uma formação plural, a um naipe de sopros e um naipe de cordas. Na impossibilidade do pintor 
de representar o conjunto de músicos necessários para produzir a sonoridade demandada num grande cortejo que atravessava as ruas de Atenas, o pintor representa um par de cada instrumento, ou somente a combinação de ambos.

Outro detalhe importante na iconografia das Panatenéias é o forte indicativo do emprego de músicos profissionais nas grandes festas cívicas - e músicos de primeiro nível, como sugere a sofisticação da indumentária dos instrumentistas da ânfora de Berlim (cat. 29). Trata-se, na verdade, do primeiro documento que retrata o luxo oriental das roupas dos músicos profissionais. Vemos, com detalhes, o fasto e refinamento característico das vestimentas dos kitharistaí: o da direita, usa uma khlaîna e um ependýtes longo, sobre um khitón branco; o último, no canto esquerdo, traz um khitón vermelho e um himátion. Os auletaí usam khitón com mangas curtas e himátion. Todas as peças, khitônes, himátia, khlaînai, ependýtes, são ricamente ornamentados, evidenciando que se tratam de vestes caras, encomendadas aos melhores costureiros disponíveis no mercado.

É necessário observarmos, como mostrou Susan Rotroff (Rotroff, 1977, p. 379-82), que existe uma aparente contradição entre o registro iconográfico (tanto dos vasos áticos como dos frisos do Partenon), nos quais aparecem a orquestra de auloí e kitharistaí e o testemunho literário de Aristófanes, que fala somente de um (ou uma?) citaredo (Aristophanes, Ecclesiazusae vs. 730-745).

Inicialmente, devemos analisar a questão do gênero: Aristófanes fala de uma citaredo, designada pelo artigo feminino, enquanto a iconografia nos mostra sempre personagens masculinos com a kithára. Durante muito tempo, tendemos a aceitar a explicação proposta por Susan Rotroff e Isabel Henderson (Henderson, 1957, p. 393), segundo as quais Aristófanes está duvidando da masculinidade dos representantes da Nova Música, personificados aqui na figura do kitharoidós - no dizer da I. Henderson, Aristófanes estava "playing for laugh". No entano, quanto mais familiaridade adquirimos com o material iconográfico ático, mais exemplos esparsos - exceções é claro - encontramos de mulheres atuando como musicistas em situações que, a princípio, pensamos serem monopólio masculino. Já vimos, anteriormente, uma mulher tocando kithára num cortejo nupcial (cat. 36; 37). Numa oinochóe de Munique, vemos uma figura com uma grande "cítara de berço", apropriada para concerto os autores discordam quanto a seu gênero, Beazley fala de um citaredo, Lullies de uma musicista, baseado no desenho da vestimenta sobre o peito, que sugere seios femininos ${ }^{\prime \prime}$. Citemos também um sarcófago tardo-arcaico, de contexto não-ático, proveniente de um sítio turco, Gumusçay, sobre o qual vemos uma mulher com uma kithára numa cerimônia funerária (Sevinç, 1996, p. 260 e 259, figs. 12-3; Bundrick, 2000, p. 26, nota 51). Destaquemos também a existência de uma lekáne com uma mulher tocando kithára diante de altar (cat. 38). Desse modo, mesmo que não possamos afirmar que o artigo feminino empregado por Aristófanes tenha uma referência realista, a iconografia está aí para insinuar a possibilidade de uma mulher atuar nesse contexto.

O segundo ponto é que Aristófanes menciona tão-somente a kithára, enquanto a iconografia, por sua vez, mostra sempre o aulós. S. Rotroff propôs a seguinte interpretação: a seção do friso do Partenon, bem como as cenas dos vasos áticos, representariam a procissão na forma que ela chegava ao santuário, após sua reorganização na chegada à Acrópole. Aristófanes, de sua parte, descreveria o cortejo sagrado através da cidade em direção da 
Acrópole. Ela propõe então que os auletaí se juntariam à procissão somente sobre a Acrópole, provavelmente por causa de seu papel no momento da imolação das vítimas. No nosso entendimento, no entanto, essa autora faz uma grande confusão. O silêncio de Aristófanes a propósito dos auletaí na procissão não é suficiente para concluirmos pela ausência desses no cortejo que percorria as ruas. Bem pelo contrário, o aulós era necessário, do ponto de vista musical, numa situação solene, tanto por causa de seu apelo visual, com os músicos vestindo um elaborado ependýtes, como pela sua função de garantir a continuidade melódica, pois fornecia mais sustentação para o canto, fator fundamental numa procissão com numerosos participantes e assistida por um grande público ${ }^{12}$. Póllux (IV.83), mesmo sendo um testemunho bastante tardio, confirma as referências da iconografia dos vasos e dos frisos do Partenon, relatando participação combinada de auletaí e kitharistai ao longo das pompai panatenaicas, contrariando a interpretação de S. Rotroff. O caso das pompaí eleusinas, analisado logo abaixo, reforça essa hipótese.

Em decorrência do conjunto de mistérios que pairavam em torno da religião de Elêusis, o silêncio acerca da maioria das práticas sagradas era um tabu em Atenas - compreende-se assim o escândalo e os temores que causou a profanação dos mistérios por Alcibíades. Uma das conseqüências desse silêncio, é o pouco conhecimento que temos da música praticada durante esses cultos. O principal estudo sobre a música no ritual eleusino se encontra num artigo de Apostolos Athanassakis, datado de 1970, provavelmente sobre a influência do texto de J. A. Haldane, publicado em 1966 (Athanassakis, 1970, p. 86-104). Com o intuito de deslindar os componentes musicais do ritual eleusino, o autor propõe o caminho profícuo da análise etimológica dos nomes dos personagens lendários identificados nas narrativas míticas da chegada de Deméter em Elêusis. Há duas versões predominantes sobre esse mito, a versão transmitida pelo Hino homérico a Deméter e a versão órfica, apresentada de forma mais acabada por Clemente de Alexandria (Clemente de Alexandria, Protr.II 20.121.2 = Kern Orphicorum fragmenta 52). Nas duas tradições, alguns personagens se repetem e outros variam. Triptolemos e Eumolpos estão nas duas versões. A referência lendária a Eumolpos era uma reminiscência viva em Atenas, uma vez que ele teria originado a família dos Eumólpidas, da qual provinham por critério hereditário os sacerdotes do culto eleusino. A denominação dos mandantes em Elêusis muda: na tradição homérica, o rei era Keleos, sua mulher, a sábia e velha Iambê, e o filho, Demophoon; na tradição órfica, o rei era Disaules, sua esposa, Baubô, e seu filho, Íaco (Iakchos).

$\mathrm{O}$ culto eleusino, que encontrava fundamento nos mitos referentes à chegada de Deméter, possuía um caráter de ritual de fertilidade. Nesse conceito grego de fertilidade, o imaginário fundia a fertilidade do solo, em que a terra (princípio feminino) é fecundada pelo grão (princípio masculino), com a fertilidade sexual. É nesse sentido que se acreditava que a bebida consumida, tanto por Deméter no mito como pelas mysthai no rito, o kykeion (preparado não alcoólico com substâncias especiais), possuía propriedades que estimulavam a fertilidade e a potência sexual. O componente sexual estava muito forte nas narrativas míticas, sobretudo na exposição da vulva por Baubô, relatada por Clemente de Alexandria, como forma de induzir a deusa ao riso.

Sob influência dessa forte conotação sexual, muitos autores procuraram seguir esse caminho para explicar os nomes dos personagens lendários. Assim, Disaules era associado 
ao pênis ("falo danado"), enquanto Baubô era associada à vulva (Athanassakis, 1970, p. 90). Sem rejeitar essa simbólica sexual dos nomes, Athanassakis procura na etimologia referências concretas sobre a música do ritual. Para esse autor, a relação evidente do nome Disaules com o aulós indica o uso desse instrumento durante um ritual de fertilidade em Elêusis. O nome Disaules indica ao mesmo tempo o instrumento utilizado e o caráter fálico do culto no qual atua, uma vez que havia na Grécia antiga uma forte conotação fálica vinculada ao formato deste instrumento musical: no grego antigo, aulískos significava, em alguns casos, o membro masculino. Nesse ponto, encontra fundamentação na analogia etnomusicológica, uma vez que a associação entre o pênis e diferentes instrumentos com morfologia do tipo da flauta é recorrente em várias culturas primitivas e até mesmo no inglês moderno, no qual aparecem expressões como "living flute" ou "silent flute" ou "oneeyed flute" (Sachs, 1949, p. 44-5; Athanassakis, 1970, p. 90-1).

No caso de Baubô, Athanassakis identifica uma alusão onomatopaica a um instrumento musical. Alguns autores já haviam recorrido à análise etimológica baseada no fenômeno da onomatopéia: uns propuseram relação com $\beta \alpha v$, "latido" no grego antigo, outros com $\beta \alpha v \beta \alpha ́ \omega$, "dormir" em Hesychius. Decompondo o nome nas partículas $\beta \alpha v$ e $\beta \alpha$, Athanassakis opina que se trata de imitações de sons - mais especificamente, do som de instrumentos de percussão. Visitando novamente a analogia etnomusicológica, lembra que é comum em várias culturas a identificação de instrumentos de percussão por meio de onomatopéias, como tambattam em tâmil ou baraban em russo. Quanto ao grego antigo, devemos concordar com Athanassakis, pois týmpanon, krotalon e kymbalon são vocábulos de forte apelo onomatopéico ao som que produzem. A utilização do týmpanon em rituais orgiásticos e de fertilidade está suficientemente documentada nos textos e na iconografia: a imagem de Cíbele com um grande týmpanon foi consagrada como seu atributo nas imagens cultuais dessa deusa, cujas estátuas e figurinhas de terracota podem ser vistas em vários museus. Posteriormente, atribuiu-se à sacerdotisa responsável pelo culto à deusa Rea o nome de $\tau u ́ \mu \tau \alpha v o v$, alusivo ao uso desse instrumento, juntamente com os krótala e auloí, nos rituais que lhe eram prestados (Hino homérico à Mãe dos Deuses, XIV.3). De certa forma, os mitos sugerem que os nomes não somente revelam os instrumentos musicais empregados, como indicam a identificação de oficiantes de culto responsáveis pela execução desses instrumentos. Consideramos a análise de Athanassakis bastante profícua, nada obstante ser demasiadamente intuitiva em alguns momentos, pois combina de forma pouco consistente a conotação sexual do ritual e a referência musical do cerimonial. Do mesmo modo como Disaules evoca o aulós que, por sua vez, evoca o phálos, Baubô nos remete ao týmpanon, que, de sua parte, nos remete à vulva, pois simbolizava a peneira que recebia o grão, com o fito de selecioná-lo para o ritual de fertilidade. Mesmo no português, há uma forte familiaridade sonora entre a "peneira" e o "pandeiro". A etnomusicologia embasa novamente essas relações, pois muitas tribos neolíticas associam o pandeiro à genitália feminina, do mesmo modo que ligam as baquetas utilizadas para percutir instrumentos de percussão ao pênis. Entende-se porque, nos estágios mais primitivos do culto, o sacerdote responsável por peneirar os grãos sagrados era chamado baubón (baqueta) (Sachs, 1949, p. 153-4; Athanassakis, 1970, p. 92-3).

Portanto, o nome da correspondente órfica de Baubô, Iambê, devia corresponder também a uma função musical, de provável efeito sugestivo onomatopéico. Já na Antigüi- 
dade, Eusthatios queria ligar Iambê ao iambos, afirmando que Iambê dançava num ritmo iâmbico (Eusthatios, 1684.48.53). Os autores modernos, além de retomarem essa explicação rítmica, apontam também a possível relação com os instrumentos iambuké e sambuké. O segundo devia ser uma pequena harpa triangular em formato de navio, com poucas cordas (Landels, 1966, p. 69 sq. Duchesne-Guillemin, 1968, p. 5 sq.); quanto à iambuké, não conseguimos precisar que instrumento seria. Athanassakis traz ainda duas outras possibilidades de interpretação do nome Iambê. Na primeira, atém-se mais ao prefixo ia-, o mesmo de Íaco (Iakchos), que aludia aos gritos proferidos durante os mistérios. Na segunda hipótese, decompõe o nome em duas partículas, iam e ba, contendo tanto a idéia do grito como do instrumento de percussão. Conclui que Iambê pudia se referir não só a um instrumento de percussão empregado e aos gritos proferidos, mas que seu nome foi assimilado à sacerdotisa que segurava esse instrumento, que talvez fosse a indecifrada iambuké (Athanassakis, 1970, p. 93-5). Conclui sua análise etimológica baseada nas onomatopéias, asserindo que Keleus simbolizaria a baqueta, princípio masculino associado ao pênis. De certa forma, a nomenclatura dos personagens, baseado na análise de Athanassakis, sugere uma divisão sexual dos papéis musicais no culto: homens tocam aulós e mulheres týmpanon, eventualmente acompanhando gritos de êxtase dos iniciados ou outros momentos do cerimonial.

Assim, Athanassakis comprova o importante papel dos instrumentos musicais, baseado no registro literário, o qual ele submete a uma leitura etimológica sustentada no fenômeno da onomatopéia e alicerçada em comparações etnomusicológicas. Em momento algum, no entanto, dedicou-se a considerar a contribuição da iconografia ática para o conhecimento da participação da música na religião de Elêusis. Dado o tabu que pairava sobre os mistérios, seguramente havia muitas restrições à forma de representar a fé eleusina na pintura. Isso resulta em nossa escassez de referências imagéticas. Entretanto, alguns testemunhos esparsos parecem endossar as conclusões de Athanassakis, além de acrescentar informações sobre algumas etapas do culto inacessível por meio de suas deduções etimológicas.

Alguns vasos áticos comprovam a utilização do týmpanon, tocado por mulheres, no culto eleusino (Nilsson, 1952, p. 562 e 565). É em algumas peças encontradas em Elêusis que encontramos outros elementos. Sobre a famosa placa votiva dedicada por Niinion, datada do início do séc. IV, conforme a descrição de Haiganuch Sarian, "há alusões precisas aos ritos, numa assembléia em que se destacam as duas deusas (Deméter e Core): no registro inferior, um cortejo de candidatos à iniciação é conduzido por Ílaco na presença de Deméter sentada próxima a uma ônfalo; no registro superior, outro cortejo dirige-se para uma figura que pode ser identificada com Core, guiada por uma phosphoros, sem dúvida Hécate" (Sarian, 1987, p. 19-25, fig. 5. Haldane, 1966, p. 101). Sobre o frontão dessa placa, encontramos uma cena bastante reveladora: vemos os mysthoi dançando ao som do aulós, como bem o destaca Haldane. No caso, o instrumento é tocado por uma figura feminina. Aristófanes nos informa que a procissão dos iniciados era anunciada, acompanhado pelo aulós, por gritos pronunciando o nome de Iakchos (Aristófanes, Rãs, 313 sq.; Haldane, 1966, p. 99).

Sobre um loutrophoros ático de figuras negras (cat. 34), conservado no Museu de Elêusis, em estado bastante fragmentário, encontramos um excepcional exemplo das pompaí eleusinas. Trata-se de um vaso do Pintor do Balanço, contemporâneo do Pintor de Berlim 1686, autor da representação mais paradigmática da orquestra panatenaica sobre a cerâmica 
(cat. 29). Do ponto de vista musical, os pintores representam o mesmo tipo de procissão: a orquestra de auletai e kitharistai se faz presente. O vaso de Elêusis corrobora os dados constantes numa inscrição, segundo a qual o aulós e a kithára participavam dos mistérios de Perséfone e Deméter, quando a música desses instrumentos complementava a dança coral e o canto por meio dos quais a história de Perséfone era narrada (S.I.G. ${ }^{3} 736,11.70$ sq).

Dado o estado fragmentário do vaso, podemos identificar com certeza dois auletaí e um kitharistés. Em nossa visita ao sítio de Elêusis, desafortunadamente nos deparamos com o museu fechado para reformas, o que nos impediu de realizar uma análise mais detalhada, pois, diante da reprodução a que tivemos acesso na obra de Elke Böher, ficamos com a suspeita de que haveria outro kitharistés atrás do primeiro: parece-nos que a extremidade superior de um dos braços do instrumento avanço sobre a zona de decoração, a qual está preservada; baseados na observação da reprodução, parece haver exatamente o espaço correspondente para esse segundo músico (Böhrer, 1982, p. 136-7). Teríamos, então, uma orquestra de pompé idêntica àquela representada nas cenas de procissões panatenaicas (cat. 29; 30). O modelo de composição orquestral não estaria ligada, então, ao deus homenageado, mas ao tipo de procissão.

A representação das pompaí panatenaicas e eleusinas repetem o mesmo esquema musical, inclusive nos detalhes protocolares, como constataram Haldane e Nordquist: os auletaí vêm sempre à frente dos kitharistaí (e dos cordófonos em geral) ${ }^{13}$. Na verdade, devem-se inserir num quadro mais amplo de emprego de música orquestrada nos rituais religiosos, até mesmo em sacrifícios, como indica um dos hinos encontrados em Delfos, que descreve os sons incisivos do aulós misturando-se com os sons doces da kithára, enquanto partes de touros queimam sobre o altar ("Hino dos curetes", in: Collectanea Alexandrina, ed. J. U. Powell, Oxford, 1925, p. 160). Luciano testemunha igualmente esse costume musical, mencionando um ritual deliano comum, no qual, enquanto os sacrifícios ardiam sobre o altar, coros de crianças aproximavam-se e dançavam no estilo do hypórchema, acompanhados pela kithára e pelo aulós. (Luciano De saltatio XVI).

Como vimos, uma das características das grandes procissões públicas é a sinaulía, a experiência da música orquestrada. A combinação instrumental mais documentada na tradição religiosa grega é a banda de auletai e kitharistaí. A iconografia nos fornece, porém, exemplos de outras combinações. Sobre um lékythos do Pintor de Gela (cat. 9), vemos um cortejo de figuras masculinas cruzando um templo, identificado pela estrutura arquitetônica de uma edícula. $\mathrm{O}$ comportamento do grupo indica uma procissão particular, na qual todos personagens estão vestindo apenas um himátion, sem vestimentas que traduzam a suntuosidade de grandes festas públicas. O caráter do cortejo se confunde com um kômos, como sugere a ação de um dos personagens, bebendo vinho de uma kýlix. No entanto, com a imagem do templo ao centro da cena, o pintor quis mostrar que a ação transcorre em espaço sagrado, portando, então, sentido religioso. Pensamos então numa procissão dionisíaca privada, na qual a divindade é cultuada como protetora do vinho e do kômos. Nesse contexto, os instrumentos musicais utilizados são recorrentes no âmbito dionisíaco: o aulós, o bárbitos e o krótalon.

Finalmente, precisamos registrar que alguns documentos imagéticos trazem, no entanto, exemplo de outra combinação instrumental em rituais com pompa pública. Sobre um fragmento de ânfora de figuras negras de Cleveland (cat. 15), datado de 530-20, estão preservadas somente as figuras de dois músicos. O cortejo musical é puxado por um adulto 
jovem, com porte atlético, barba e cabelos longos, que está tocando um instrumento de cordas, cuja maior parte está perdida. Identificamos esse instrumento como um bárbitos, baseados exclusivamente na curvatura do braço do instrumento, imprópria para uma lýra. A seguir, vem um kitharistés, barrigudo, com barba e traços senis, vestindo um khitón com manga curta e um himátion enfeitado com bordados. A interpretação desse fragmento encontra amparo na comparação com uma cena mítica de sacrifício, que deve estar referenciada em práticas cultuais reais. Trata-se de uma hydría parisiense do Pintor de Kleophrades (cat. 16), onde vemos a seguinte cena: Héracles levado ao altar para ser sacrificado qual uma vítima, liberta-se e ataca Bousiris, no momento em que a procissão sacrificial já havia chegado ao altar, ao lado do qual estava depositada uma grande cratera com voluta; diante da reação de Héracles, três personagens que participavam da procissão se afastam, dentre eles um jovem com um bárbitos e um adulto barbado com uma kithára. Os trajes - simples mantos - mostram os músicos como cidadãos comuns e não como músicos profissionais. Juntando à ânfora de Cleveland à hydría de Paris, temos a evidência do emprego combinado da kithára e do bárbitos, tanto ao longo da procissão quanto no santuário diante do altar.

\section{Conclusão}

Apesar de ser o aulós o instrumento mais característico no acompanhamento dos hinos e coros processionais, vários exemplos testemunham o uso de outros instrumentos, sobretudo de cordófonos, como a kithára, dependendo da tradição musical do repertório usado no ritual ou da divindade homenageada, não sendo este último um cretério determinante. No caso das grandes procissões públicas, como as Panatenéias em Atenas, uma orquestra de músicos acompanhava o ritual, conferindo-lhe mais pompa e maior sonoridade.

\section{Catálogo Iconográfico}

\section{(Cerâmica ática de figuras negras e vermelhas)}

1. Ânfora. Figuras negras. Ático corintizante. Sem atribuição. (Para 33) Paris, Louvre, E 861 (Campana 273). Primeira metade do séc. VI.

2. Khoûs. Figuras negras. Pintor de Amásis. (ABV 153/43) Orvieto, Museo Claudio Faina, 1001. 560-50.

3. Skýphos. Figuras negras. Grupo do Comasta. Pintor de KX. (ABV 26/21; Add $^{2} 7$ ) Atenas, Museu Nacional, 640. 585-80.

4. Pínax. Figuras negras. Sem atribuição. Atenas. Museu Nacional, Coleção da Acrópole, 25742575. Terceiro quartel do século VI.

5. Ânfora. Figuras negras. Pintor do Balanço (The Swing Painter). (Beazley) Nápoles, Museo Nazionale, 81186. 550-30.

6. Loutrophóros (fragmento do pé). Figuras negras. Sem atribuição. Atenas, Museu Nacional, Coleção da Acrópole, 1208. Final do século VI.

7. Cratera em cálice. Pintor de Villa Giulia. Roma, Villa Giulia, 909. 
8. Ânfora (fragmento). Figuras vermelhas. Maneira do Pintor de Kleophon. (ARV2 1150/30) Atenas, Museu da Ágora, P 7912. Em torno de 430.

9. Lékythos. Figuras negras. Pintor de Gela. (ABL 206/17) Gela, Museo Archeologico Nazionale, 126/B (antigo inventário). Em torno de 510.

10. Kýlix em forma de cratera. Figuras negras. Pintor do B.M.N. Paris, Louvre, CA 2988 Pouco depois da metade do século VI.

11. Kýlix. Figuras vermelhas. Pintor de Triptolemo. Paris, Louvre, G 138. Em torno de 480.

12. Ânfora. Figuras negras. Affekter. (ABV 243) Munique, Staatliche Museen, Antikensammlung, 1441.540-30

13. Skýphos. Figuras negras. Pintor de Teseu. (Para 258, acima) Stuttgart, Würtemberger Landesmuseum, KAS 74. Em torno de 500.

14. Ânfora. Figuras negras. Pintor de Amásis. (ABV 151/11; Para 63) Berlim, Staatliche Museen, Antikensammlung, F 1690. 560-50.

15. Ânfora (fragmento). Figuras negras. Sem atribuição. Cleveland, The Cleveland Museum of Art, 24.536. 530-20

16. Hydría. Figuras vermelhas. Pintor de Kleophrades. (ARV² 188/70) Paris, Louvre, N 3376 (MN 401). Final do séc. VI.

17. Cratera. Figuras negras. Pintor de Ptoon. (ABV 83/1) Paris, Louvre, E 623 (Campana 38). 580-70.

18. Ânfora de colo ovóide. Figuras negras. Pintor de Omaha. (Para 34/2; Add² 24) Omaha/Nebraska, Joslyn Art Museum, 1963.480. Em torno de 570.

19. Kýlix (Siana). Figuras negras. Pintor C. (ABV 51/5) Londres, Museu Britânico, B 282. 575-55.

20. Hydría. Figuras vermelhas. Pintor de Christie. (ARV² 1049/49; Add ${ }^{2} 321$ ) Gotta, Schlossmuseum, 53. Em torno de 440.

21. Fragmento (tipo de cratera em sino). Figuras negras. Sem atribuição. Atenas, Museu Nacional, Coleção da Acrópole, 621. Último quartel do século VI.

22. Pyxís. Figuras negras. Sem atribuição. Atenas, Museo Nacional, sala 54, vitrine 52 (em abril de 1998). Em torno de 500.

23. Stámmos. Figuras vermelhas. Pintor de Vila Giulia. (ARV²620/32) São Petersburgo, Hermitage, 1588 (B 806). Em torno de 460.

24. Cratera com colunas. Figuras vermelhas. Grupo dos Maneiristas. Talvez da mesma mão do Pintor da Phiále de Berlim, Charlottenburg, 3223. (PARIBENI). Milão, Colezione HA, C. 316. Segundo quartel do século $\mathrm{V}$.

25. Stámmos. Figuras vermelhas. Deepdene Painter. (ARV² 499/10; Add 251 ). Varsóvia, Museu Nacional, 142351. (Anteriormente, Goluchov, Museu Czartoryski, 44). Segundo quartel do século $\mathrm{V}$.

26. Fragmentos (provavelmente de um kántharos com duas alças). Figuras vermelhas. Pintor de Pã. Fragmentos encontrados em Menidi/Ática, nas escavações de abri/maio de $1878, \mathrm{n}^{\circ} 1$. Metade do século V. Provavelmente contemporâneo dos frisos do Partenon.

27. Lélythos (fragmentos). Figuras negras. Sem atribuição. Atenas, Museu Nacional, Coleção da Acrópole, 2298. Em torno de 500.

28. Kýlix. Figuras negras. Próximo de Glaukytes. Suíça, Basiléia, Coleção privada (foto: Herbert Cahn, Basiléia). Em torno de 560.

29. Ânfora. Figuras negras. Pintor de Berlim 1686. (ABV 296/4; $\operatorname{Add}^{2} 77$ ). Berlim, Staatliche Museen, Antikensammlung, 1686. 540-30.

30. Fragmentos: Figuras negras. Sem atribuição. Fragmentos encontrados em Menidi/Ática, nas escavações de abril/maio de $1878, n^{\circ} 9$. Últimas décadas do século VI. 
31. Fragmentos. Figuras negras. Sem atribuição. Atenas, Museu Nacional, Coleção da Acrópole, 2009. Final do século VI.

32. Ânfora (fragmentária). Figuras negras. Atenas, Museu Nacional, Coleção da Acrópole, 816. Em torno de 500.

33. Kýlix. Figuras negras (imitação beócia?). "Early attic work, known as Vaurna". (CVA Museu Britânico 2, III H e, pr. e.4a-b) Alguns autores identificam peça como produto de indústria beócia, outros como imitação beócia de modelo ático. Londres, Museu Britânico. B 80. Primeiro quartel do século VI.

34. Loutrophóros. Figuras negras. Pintor do Balanço (The Swing Painter). (ABV 309/97; Para 133; $\operatorname{Add}^{2} 83$ ) Elêusis, Museu Arqueológico, 471 (873). 550-30.

35. Hydría. Figuras negras. Sem atribuição. Paris, Louvre, F 10. Meados do séc. VI.

36. Ânfora de colo. Figuras negras. Grupo de Leagros. Berlim, Antikesammlung, F 1896. Final do século VI.

37. Kýlix. Figuras vermelhas. Pintor de Anfitrite. (ARV2 831/20) Berlim, Staatliche Museen, F 2530. Final da primeira metade do século V.

38. Lekáne. Figuras vermelhas. Sem atribuição. São Petersburgo, Hermitage. Terceiro quartel do séc. V.

\section{Notas}

1 - Xenofonte, República dos Lacedemônios XIII.8: “[...] Quando o carneiro está sendo sacrificado, o inimigo estando ao alcance da vista, o costume ordena que todos os auletaí presentes devem tocar e que todos os lacedemônios devem colocar uma guirlanda"; Ésquilo, Sete contra Tebas 267: "[...] Possam os deuses lutar ao nosso lado".

2 - Relação entre a pobreza e os músicos de funerais: Eliano, Varia historia 12.43.

3 - Somente em cat. 2 temos a evidência da lýra como acompanhamento musical da procissão.

4 - Em cat. 345.1 a procissão já se encontra junto ao altar, quando se dispersa devido à reação de Héracles.

5 - Kýlix de Siana. Figuras negras. Pintor de Taras. Amsterdã, Allard Pierson Museum, Universidade de Amsterdã, 13.367. Em torno de 565. Bib.: CVA Amsterdã 2 (Holanda 8) pr. 68.5; 69; 70.

6 - Na sociedade coríntia retratada em vasos contemporâneos ou pouco anteriores, é a lýra que se destaca no banquete. Cf. Cratera. Coríntio médio. Pintor de Athana. Paris, Louvre, E 629. 590-75.

7 - Sobre a partilha da khlaîna por pares homoeróticos masculinos e femininos e pares heterossexuais, como símbolo da relação de philia, cf. Calame, Claude. L'Éros dans la Grèce antique. Paris: Bélin, 1996, p. 136.

8 - ABV 518. Cf. Vaso de figuras negras. Pintor de Teseu. (ABV 704/27ter; Add2 129) Tampa/ Flórida, anteriormente, Maplewood, coleção Noble, 25.

9 - Em se tratando apenas de um fragmento, deduzimos que o contexto representaria a chegada da procissão sacrifical ao santuário, uma vez que nenhum vaso de figuras vermelhas retrata o percurso da procissão.

10 - Inscrição do séc. II a.C., descoberta nas expedições francesas a Delfos de 1893-4. Sobre os hinos a Apolo de Delfos, cf. Bélis, Annie. Les hymnes à Apollon. Étude épigraphique et musicale. Corpus des Inscriptions de Delphes. Tomo III, Paris: Boccard, 1992. Discografia: De la pierre au son. Musique de l'Antiquité Grecque et Romaine. Ensemble Kérylos. Direção: Annie Bélis.

11 - Bezley ARV² 10/4. Lullies in: CVA Munique 2, texto referente à pr. 84. 
12 -(Ps.-) Aristóteles Problemas XIX.43: defende que a aulódia leva vantagem sobre a liródia, no sentido de que o aulós se une com a voz, pois são ambos instrumentos de sopro, com um som contínuo, de modo que o aulós tapa os erros do canto, aos ouvidos do público; a lýra, para o espectador, é menos perceptiva e, em não sendo soprada, não casa no ouvido com o som da voz - seu som sendo magro, produz sempre a impressão de ser separado da voz. Haldane, 1966, p. 100: "Naturally the kithára, lacking the stronger tones of the aulós, would by itself have formed insufficient support for the heavier type of procession. It was, however, eminently suited for the graceful advance of a group of dancers."

13 -Haldane, 1966, p. 101; Nordquist, 1992, p.149-50: a única exceção é a placa de Pitsia, que registra um sacrifício realizado no âmbito familiar, onde vemos um menino com lýra à frente do outro, um pouco menor, com aulós; segundo Nordquist (p. 163-5), deveríamos imaginar que os dois garotos estariam lado a lado diante do altar, executando uma sinaulía. Ver, sobre procissões com aulós e kithára: Eitrem, S. Beiträge zur griechischen Religionsgeschichte. Christiania, 1920, III, p. 94.Referências bibliográficas

\section{Referências bibliográficas}

ATHANASSAKIS, Apostolos N. Music and ritual in primitive Eleusis. Platon, 28, 1970, p. 86-104.

BÉLIS, Annie. Musique et transe dans le cortège dionisyaque. Cahiers du GITA 4, 1986, p. 9-29.

Les musiciens dans l'Antiquité. Paris: Hachette, 1999.

BÖHER, Elke. Der Schaukelmahler. Kerameus 4, Mainz: Verlag Philipp von Zabern, 1982, p. $50, n^{\circ} 132$, pr. $136-7$.

BUNDRICK, Sheramy Deanna. Expression of harmony: Representation of female musicians in fifth-century athenian vase painting. (disseração) Michigan: UMI - Dissertation Service, 2000 (1998).

DUCHESNE-GUILLEMIN, Marcelle. Restituition d'une harpe minoenne e le problème de la SAMBUKH. Ant Cl 37, 1968, p. 5 sq.

FURTWÄNGLER-REICHHOLD. Griechische Vasenmalerei. Munique, 1932, III.

GHIRON-BISTAGNE, P. Recherches sur les acteurs dans la Grèce antique. Paris: Les Belles-Lettres, 1976, p. 296.

HALDANE, J. A. Musical instruments in Greek worship. Greece and Rome, 13, 1966, p. 98-107.

HENDERSON, Isabel. Ancient Greek music. In: New Oxford History of Music, I: Ancient and Oriental Music, 1957.

LANDELS, J. G. Ship-shape and Sambuca-Fashion. JHS 86, 1966, p. 69sq.

LEHNSTAEDT, K. Prozessionsdarstellungen auf attischen Vasen. Dissertação, Munique, 1970.

NILSSON, M. P. Die eleusinischen Gottheiten. In: Opuscula Selecta, vol. II, Lund, 1952.

NORDQUIST, G. "Instrumental music in representations of Greek cult.". In:: Kernos, Supl. 1 (HÄGG, Robin. The iconography for Greek cult in the archaic and classical periods. 
Proceedings of the First International Seminar on Ancient Greek Cult. Organized by the Swedish Institute at Athens and the European Cultural Centre of Delphi.), 1992.

. "The salpínx in Greek cult". AHLBÄCK, Tore. (ed.) Dance, music, art and religion. Based on papers read at the Symposion on Dance, Music and Art in Religions Held at Abo, Finland, on the $16^{\text {th }}-18^{\text {th }}$ August 1994, Abo/Estocolmo: 1994, p. 241-56.

. "Some notes on musicians in Greek cult.", p. 81-93 (separata sem referências).

ROTROFF, Susan. The Partenon frieze and the sacrifice to Athena. AJA 81, 1977, p. 37982.

SACHS, Kurt. The history of the musical instruments. Nova Iorque, 1949, p. 44-5.

SARIAN, Haiganuch. "A expressão imagética do mito e da religião nos vasos gregos e de tradição grega", In: BRANDÃO, Jacyntho Lins \& PINTO, Neiva Ferreira. (Org.) Cultura Clássica em Debate. Estudos de Arqueologia, História, Filosofia, Literatura e Lingüística greco-romana. Anais do I Congresso Nacional de Estudos Clássicos. Belo Horizonte: UFMG/CNPq/SBEC, 1987, p. 19-25, fig. 5.

SEVINÇ, N. A new sarcophagus of Polyxena from the Salvage Excavations at Gumusçay. Studia Troica 6, 1996, p. 260 e 259.

SIMON, Erika. Öpfernde Götter. Berlim: Verlag Gebr. Mann, 1953.

CERQUEIRA, Fábio Vergara. Music and worship. Essay on the musical accompaniment of Athenian processions according to the testimony of ancient texts and of late-archaic and classic Attic pottery. Classica, São Paulo, 13/14, p. 81-100, 2000/2001.

\begin{abstract}
Music was a component of Greek ritual, playing an important role, both in the ceremonial and in the mystic aspects. The subject of this paper is the musical accompaniment of processions, focusing the Athenian case, attested by the iconographical register of Attic pottery, concerning the world of Athens in the sixth and fifth centuries. The iconographical evidence is considered in a wide context of Greek religion, making comparisons with other regions and periods of Antiquity, based on the ancient texts.
\end{abstract}

KEYWORDS: Ancient Greece; music; religion; iconography. 